\title{
Tau Protein in Lung Smooth Muscle Cells
}

\author{
Nataliia V. Shults ${ }^{1}$, Sarah Seeherman ${ }^{1}$, Nurefsan E. Sariipek ${ }^{1}{ }^{1}$, Vladyslava Rybka ${ }^{1}$, \\ Lucia Marcocci ${ }^{2}$, Sergiy G. Gychka ${ }^{3}$, Yasmine F. Ibrahim ${ }^{4}$ and Yuichiro J. Suzuki ${ }^{1, *}$ \\ 1 Georgetown University Medical Center, Department of Pharmacology and Physiology, \\ Washington, DC 20007, USA; ns1015@georgetown.edu (N.V.S.); sseeherman77608@med.lecom.edu (S.S.); \\ n.eminesariipek@gmail.com (N.E.S.); rybkavladyslava@gmail.com (V.R.) \\ 2 Department of Biochemical Sciences “A. Rossi Fanelli", Sapienza University of Rome, 00185 Rome, Italy; \\ Lucia.Marcocci@uniroma1.it \\ 3 Department of Pathological Anatomy N2, Bogomolets National Medical University, 01601 Kiev, Ukraine; \\ gychka59@gmail.com \\ 4 Department of Pharmacology, Minia University Faculty of Medicine, Minia 61511, Egypt; \\ yasmine.ibrahim@mu.edu.eg \\ * Correspondence: ys82@georgetown.edu; Tel.: +120-2687-8090
}

Received: 2 November 2020; Accepted: 26 November 2020; Published: 29 November 2020

\begin{abstract}
Tau, a microtubule-associated protein, plays a critical role in the pathophysiology of neurons. However, whether tau protein is expressed in smooth muscle cells is unknown. Thus, we tested the hypothesis that tau protein is expressed in the primary cultures of smooth muscle cells. Here, we report that tau protein is expressed and constitutively phosphorylated at threonine 181 in various smooth muscle cell types, including human pulmonary artery smooth muscle cells, bronchial airway smooth muscle cells, and cerebral artery smooth muscle cells. Immunofluorescence staining revealed that phosphorylated tau at threonine 181 is more organized in the cell than is total tau protein. A protein phosphatase inhibitor, calyculin A, induced the formation of higher molecular weight species of phosphorylated tau, as visualized by Western blotting, indicating the occurrence of tau aggregation. Immunofluorescence analysis also showed that calyculin A caused the aggregation of phosphorylated tau and disrupted the cytoskeletal organization. These results demonstrate the existence of tau protein in smooth muscle cells, and that smooth muscle tau is susceptible to protein phosphorylation and aggregation. Lung smooth muscle tau may therefore play an important role in pulmonary pathophysiology.
\end{abstract}

Keywords: aggregation; phosphorylation; protein; smooth muscle; tau

\section{Introduction}

Tau is a microtubule-associated and natively unfolded protein, implicated in the pathogenesis of Alzheimer's disease and well-studied in the brain [1]. Tau promotes the self-assembly of tubulin into microtubules and plays a role in microtubule stabilization in the cell $[2,3]$. Under physiological conditions, tau is a stabilizer of microtubules and regulates cell differentiation and proliferation [4-6]. However, under pathological conditions, tau proteins assemble into insoluble aggregates [7-10]. Tau protein aggregation in the brain is a hallmark of Alzheimer's disease, the most common neurodegenerative dementia [11-15]. In addition, the abnormal deposition of misprocessed and aggregated tau proteins in the nervous system contributes to the development of supranuclear palsy, corticobasal degeneration, Pick's disease, Huntington's disease, argyrophilic grain disease, frontotemporal dementia and parkinsonism linked to chromosome 17, and globular glial tauopathy [16-22]. The phosphorylation of tau contributes to disease-associated tau toxicity [13,23-26]. Tau is also expressed in non-neural cells, including fibroblasts and lymphocytes [27,28]. 
Tau is a microtubule-associated protein that promotes the polymerization and assembly of microtubules, and is considered to be one of the most important proteins in the pathology of the central nervous system [6]. It is located in the cellular compartment as well as in the interstitial fluid [29]. The abnormal accumulation of misprocessed tau is associated with various neurodegenerative diseases [30]. It has recently been shown that tau has multiple functions in addition to axonal microtubule assembly. It binds to nucleic acid and modulates gene expression and RNA stability [31]. Under pathological conditions, tau causes DNA and RNA damage, nuclear disorganization, RNA and ribosome instability, and changes in protein expression [32-34]. Tau may also modulate and impair cell signaling, contributing to altered receptor activities and cell death $[13,35,36]$.

Since it is not known if tau protein is expressed in the lung or in smooth muscle cells, the present study examined the expression of tau protein in smooth muscle cells, particularly in the lungs. We found that various types of smooth muscle cells, including those in the pulmonary vessels and airways, express tau protein, which is subjected to protein phosphorylation and aggregation. These results are the first to indicate the possible pathophysiological importance of tau in the lungs.

\section{Experimental Section}

\subsection{Histology}

Postmortem brain tissues were collected from patients with a history of systemic hypertension and who died of ischemic stroke. The tissues were taken from the perifocal zone of the ischemic infarct in the region of the middle cerebral artery of the frontal lobe. The clinical studies were approved by the regional committee for medical research ethics in Kiev, Ukraine (ethical code: 81, 2016) and performed under the Helsinki Declaration of 1975, revised in 2013, or comparable ethical standards.

Brain tissues were immersed in buffered 10\% formalin at room temperature and embedded in paraffin. The paraffin-embedded tissues were cut and mounted on glass slides. The tissue sections were subjected to immunohistochemistry using the tau antibody (MilliporeSigma, Burlington, MA, USA).

\subsection{Cell Culture}

Human brain vascular smooth muscle cells (Catalog \# 1100), human pulmonary artery smooth muscle cells (Catalog \# 3110), and human bronchial smooth muscle cells (Catalog \# 3400) were purchased from ScienCell Research Laboratories (Carlsbad, CA, USA). The cells were cultured in accordance with the manufacturer's instructions in $5 \% \mathrm{CO}_{2}$ at $37^{\circ} \mathrm{C}$. They were then treated with calyculin A or $\mathrm{H}_{2} \mathrm{O}_{2}$ purchased from MilliporeSigma. For the siRNA experiments, the cells were transfected with an siRNA Transfection Reagent and control, tau (h) or tau (h2) siRNA from Santa Cruz Biotechnology (Dallas, TX, USA). Finally, $48 \mathrm{~h}$ later, the cell lysates were prepared.

\subsection{Western Blotting}

To prepare the cell lysates, the cells were washed in phosphate-buffered saline and solubilized with lysis buffer containing $50 \mathrm{mM}$ Hepes ( $\mathrm{pH}$ 7.4), 1\% (v/v) Triton X-100, 4 mM EDTA, 1 mM sodium fluoride, $0.1 \mathrm{mM}$ sodium orthovanadate, $1 \mathrm{mM}$ tetrasodium pyrophosphate, $2 \mathrm{mM} \mathrm{PMSF}, 10 \mu \mathrm{g} / \mathrm{mL}$ leupeptin, and $10 \mu \mathrm{g} / \mathrm{mL}$ aprotinin. The samples were then centrifuged at $16,000 \mathrm{~g}$ for $10 \mathrm{~min}$ at $4{ }^{\circ} \mathrm{C}$. Finally, the supernatants were collected, and protein concentrations determined. 
Equal amounts of protein samples were electrophoresed through a reducing sodium dodecyl sulfate polyacrylamide gel. The proteins in the gel were then electro-transferred to the Immobilon-FL Transfer Membrane (MilliporeSigma, Burlington, MA, USA). The membrane was blocked with Odyssey blocking buffer (LI-COR, Lincoln, NE, USA) for $1 \mathrm{~h}$ at $25^{\circ} \mathrm{C}$ and incubated overnight with the rabbit anti-tau (C-terminal) antibody (MilliporeSigma) or mouse anti-phospho-tau (Thr181) Clone AT270 antibody (Thermo Fisher Scientific, Waltham, MA, USA) at $4{ }^{\circ} \mathrm{C}$. The washed membranes were then incubated with IRDye 680RD or IRDye 800CW (LI-COR) for $1 \mathrm{~h}$. The signals were obtained using the Odyssey Infrared Imaging System (LI-COR). IRDye 680RD or IRDye 800CW secondary antibodies alone did not produce any signals in the absence of primary antibodies.

\subsection{Immunofluorescence Analysis}

The immunofluorescence analysis of tau protein and phosphorylated tau at threonine 181 was performed on $70 \%$ confluent human pulmonary artery smooth muscle cells. The cells were fixed with $4 \%$ paraformaldehyde for $15 \mathrm{~min}$, permeabilized with $0.25 \%$ Triton X-100 for $10 \mathrm{~min}$, and blocked with $5 \% \mathrm{BSA}$ for $1 \mathrm{~h}$ at room temperature. The cells were labeled with the rabbit anti-tau (C-terminal) antibody (MilliporeSigma) or mouse anti-phospho-tau (Thr181) Clone AT270 antibody (Thermo Fisher Scientific) at room temperature at a dilution of 1:1000 in 1\% BSA for $1 \mathrm{~h}$ and then labeled with the Alexa Fluor488 secondary antibodies at a dilution of 1:500 for $30 \mathrm{~min}$ at room temperature. Alexa Fluor488 alone did not give non-specific green staining in human pulmonary artery smooth muscle cells. F-actin was stained with Alexa Fluor 594 phalloidin, and the nuclear staining was performed using 4',6-diamidino-2-phenylindole (DAPI). The slides were examined using an Olympus BX61 DSU Fluorescence microscope. Digital fluorescence micrographs were recorded and analyzed with the ImageProPlus software.

\subsection{Statistical Analysis}

Means \pm standard error of the mean (SEM) were calculated and then comparisons between two groups were performed using a Student's $t$ test, while comparisons between three or more groups were performed using ANOVA. $p<0.05$ was considered statistically significant.

\section{Results}

\subsection{Tau Protein is Expressed and Constitutively Phosphorylated at Threonine 181 in Smooth Muscle Cells}

Tau protein expressed in neuronal cells is known to play a key role in neurological disorders. However, whether smooth muscle cells express tau protein is unknown. Thus, we first examined tau protein expression in the brains of human patients who died of ischemic stroke by immunohistochemistry. As shown in Figure 1a, tau protein expression was detected in the neuronal tissues, as expected. The smooth muscle layer of cerebral vessels was also positive for tau protein expression (Figure 1a, arrows). Similar results showing the expression of tau protein in brain vascular smooth muscle cells were obtained from three patients.

Similarly, tau protein expression was also detected by Western blotting in the cell lysates prepared from cultured human brain vascular smooth muscle cells (Figure 1b). Two sequences of siRNA reduced the intensity of the band, confirming that this $\sim 40 \mathrm{kDa}$ band is indeed tau protein expressed in smooth muscle cells (Figure 1b). We also found that tau protein expressed in human brain vascular smooth muscle cells is constitutively phosphorylated, as detected by Western blotting using an antibody that recognizes phosphorylated tau at threonine 181 (Figure 2). Interestingly, tau protein expression was also detected in the human pulmonary artery smooth muscle cells of the lung vasculature, as well as in the human bronchial smooth muscle cells of the airways (Figure 2). This is the first demonstration of the expression of tau protein in smooth muscle cells, as well as in lung components. 
a
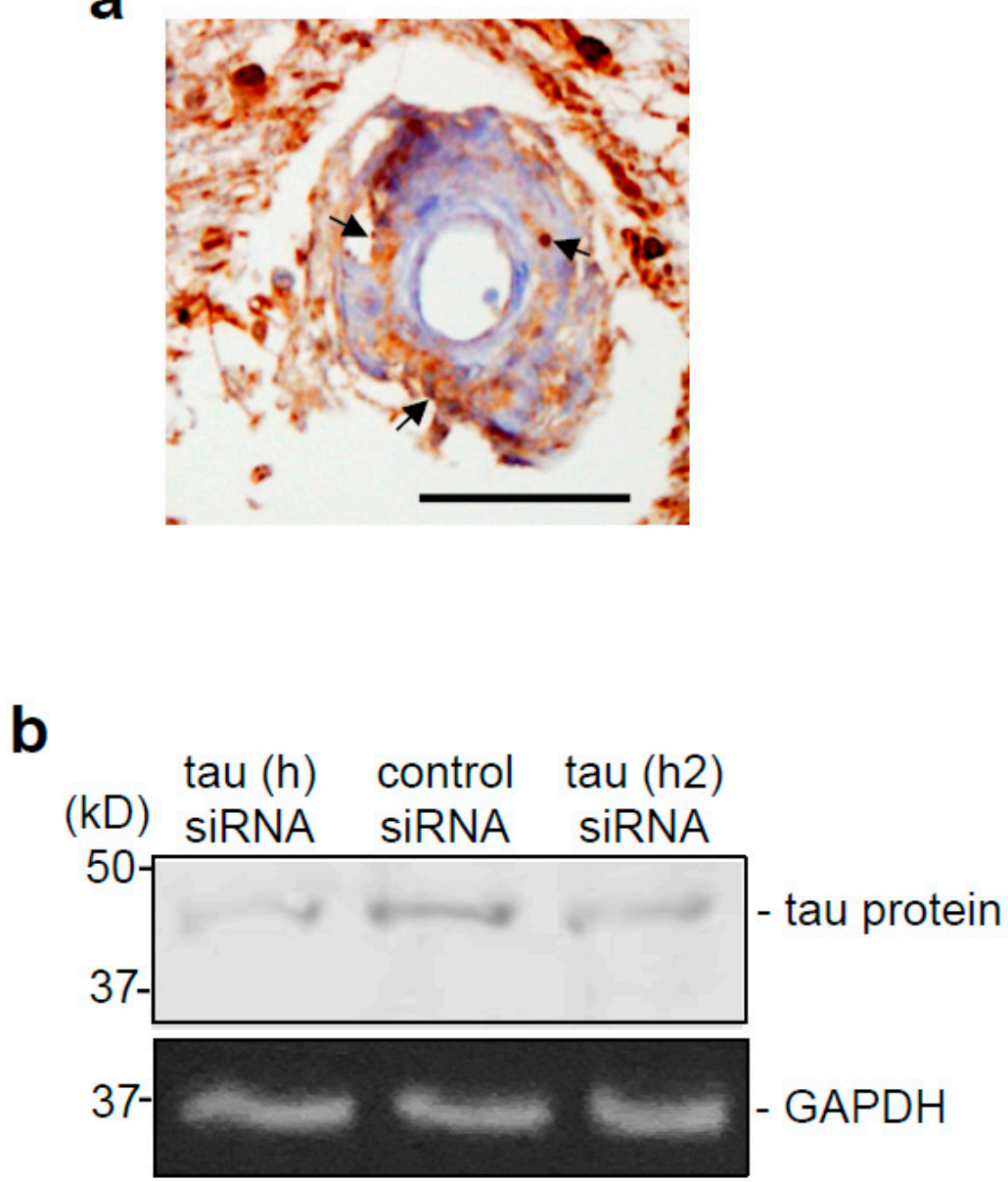

Figure 1. Tau protein is expressed in smooth muscle cells. (a) Immunohistochemistry shows that tau protein is expressed in the brain vascular smooth muscle tissues of patients with systemic hypertension who died of ischemic stroke. Magnification $\times 40$. Scale bar, $50 \mu \mathrm{m}$. (b) Cultured human brain vascular smooth muscle cells transfected with control, tau (h) or tau (h2) siRNA. $48 \mathrm{~h}$ later, cell lysates were prepared. Western blooming with tau protein and GAPDH protein antibodies.

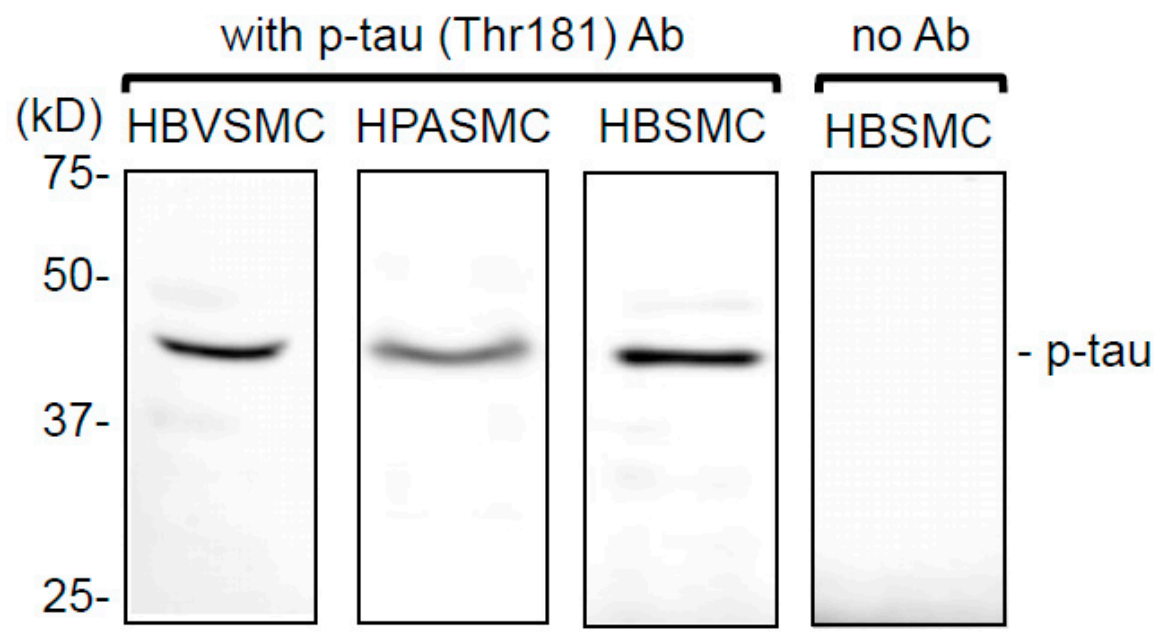

Figure 2. Threonine 181 of tau protein is constitutively phosphorylated in smooth muscle cells. Cell lysates prepared from cultured human brain vascular smooth muscle cells (HBVSMC), human pulmonary artery smooth muscle cells (HPASMC), and human bronchial smooth muscle cells (HBSMC) were subjected to Western blotting using the antibody $(\mathrm{Ab})$ against phosphorylated tau ( $\mathrm{p}$-tau) at threonine 181 (Thr181). The secondary Ab-only control without the p-tau antibody is also shown. 


\subsection{Cytoskeletal Organization of Tau and Phosphorylated Tau in Lung Vascular Smooth Muscle Cells}

Immunofluorescence staining using the tau antibody showed dispersed total tau protein expression in the cytoplasm of human pulmonary artery smooth muscle cells (Figure 3a). By contrast, tau protein phosphorylated at threonine 181 was found to be associated with the microtubule, and is well organized in the cytoplasm, as determined by immunofluorescence staining using the phospho-specific tau antibody (Figure 3b).
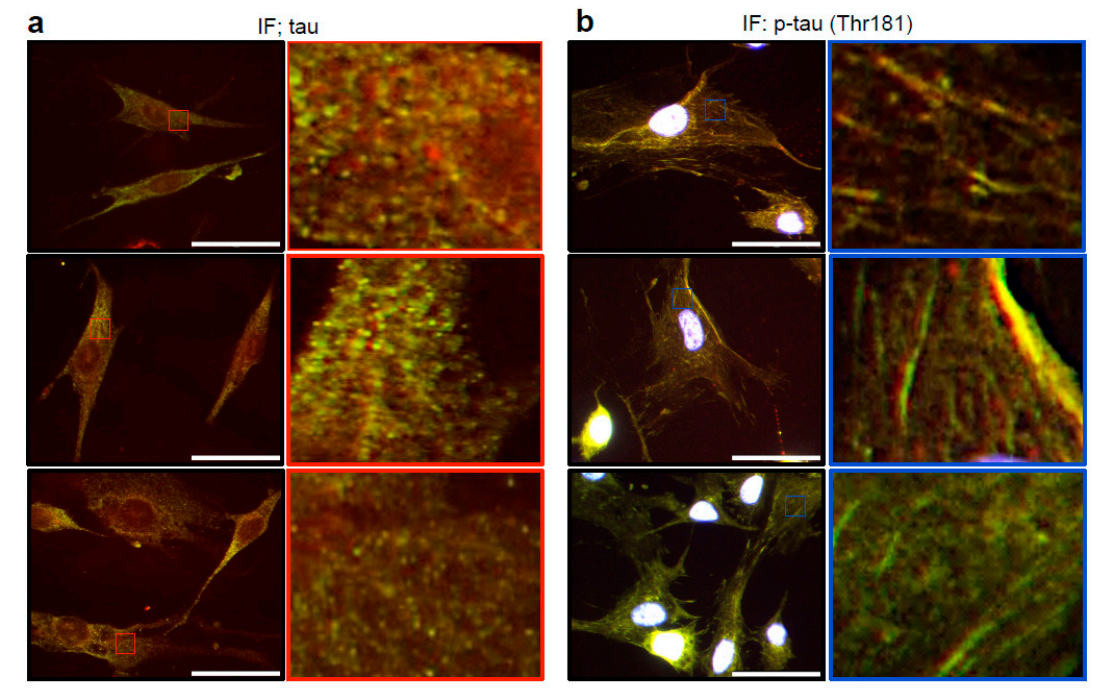

Figure 3. Tau protein phosphorylated at threonine 181 is highly organized in smooth muscle cells. Untreated human pulmonary artery smooth muscle cells were subjected to immunofluorescence (IF) analysis using (a) the tau protein antibody and (b) the phospho-specific tau (Thr181) antibody (p-tau). The areas indicated with squares are shown enlarged on the right side of each image. Three representative images are shown for each case. The green color indicates tau or p-tau antibody staining, the red color shows F-actin, and the nuclear staining was performed using DAPI. These images show the well assembled network of phosphorylated tau localized along the microtubules, while tau protein molecules that are not phosphorylated at threonine 181 are not well organized. Scale bars, $50 \mu \mathrm{m}$.

\subsection{Effects of Calyculin A in Lung Vascular and Airway Smooth Muscle Cells}

Calyculin A is an inhibitor of protein phosphatases types 1 and 2A that should promote cellular protein phosphorylation [37,38]. Our Western blotting experiments revealed that calyculin A produced multiple higher molecular weight species that can be detected by the phospho-tau (Thr181) antibody in human pulmonary artery smooth muscle cells (Figure 4a). These higher molecular weight species largely occurred at about 80 and $160 \mathrm{kDa}$; they can be induced after just $10 \mathrm{~min}$ of cell treatment with calyculin A, and their formation continues to increase for $30 \mathrm{~min}$ (Figure 4a). By contrast, subjecting cells to oxidative stress by hydrogen peroxide treatment did not induce such higher molecular weight species (Figure 4a). The molecular weights of 80 and $160 \mathrm{kDa}$ are consistent with the multimers of tau protein. These may be the products of phosphorylation-dependent tau aggregation. With light microscopy, it was visible that cells get rounded up in response to calyculin $\mathrm{A}$, while no visible changes were observed in $\mathrm{H}_{2} \mathrm{O}_{2}$-treated cells. 

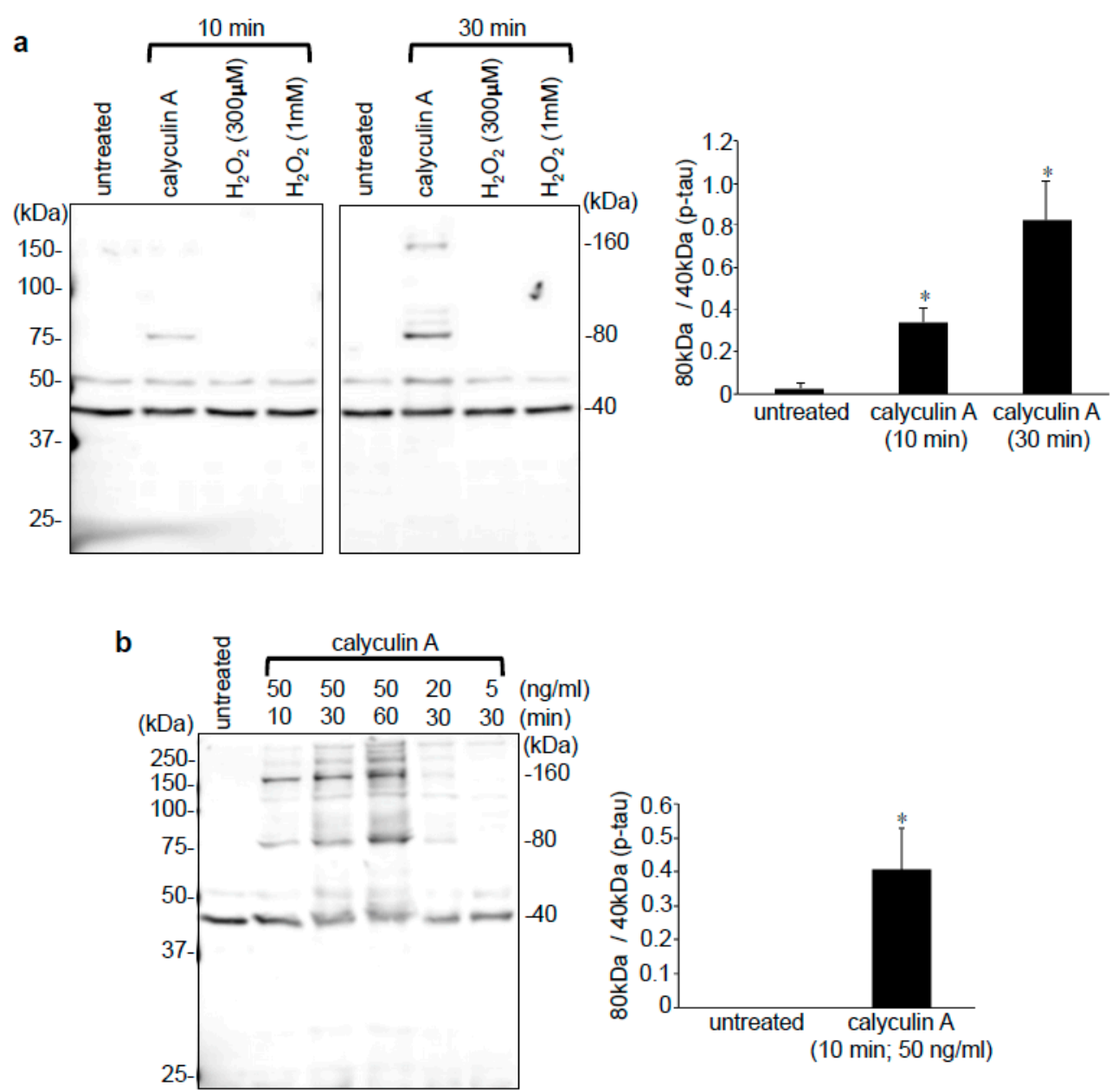

Figure 4. Calyculin A forms high molecular phosphorylated tau species. (a) Human pulmonary artery smooth muscle cells were treated with calyculin A $(50 \mathrm{ng} / \mathrm{mL})$ or hydrogen peroxide $\left(\mathrm{H}_{2} \mathrm{O}_{2}\right)$ for the durations indicated. (b) Human bronchial smooth muscle cells were treated with various doses of calyculin A for the durations indicated. Cell lysates were subjected to Western blotting with the antibody against phosphorylated tau at threonine 181 (p-tau). Bar graphs represent means \pm SEM of the ratio of $80 \mathrm{kDa}$-tau band to $40 \mathrm{kDa}$-tau band $(\mathrm{N}=3-4) .{ }^{*}$ Significantly different from untreated at $p<0.05$.

Similarly, these high molecular weight species were also detected in airway smooth muscle cells treated with calyculin A. Figure $4 \mathrm{~b}$ shows that the treatment of human bronchial smooth muscle cells with calyculin A at $50 \mathrm{ng} / \mathrm{mL}$ caused the formation of the higher molecular weight species of tau at 80, 120,160 , and perhaps 200 or $240 \mathrm{kDa}$ in a time-dependent manner. The formation of higher molecular weight species occurred after just $10 \mathrm{~min}$, and continued to increase (Figure $4 \mathrm{~b}$ ). The dose-dependence of calyculin A at 5,20 and $50 \mathrm{ng} / \mathrm{mL}$ was also observed (Figure $4 \mathrm{~b}$ ). We repeatedly and consistently observed the formation of calyculin A-induced higher molecular weight species, as visualized using the phospho-tau (Thr181) antibody in smooth muscle cells in at least 10 separate experiments.

Immunofluorescence staining demonstrated that the treatment of human pulmonary artery smooth muscle cells with calyculin A disrupted the well-organized cytoskeletal structure of tau phosphorylated at threonine 181 and formed some protein aggregates, as indicated by the arrows in Figure 5a. The quantification of the number of phosphorylated tau aggregates per cell showed that calyculin A significantly increased the aggregation (Figure 5b). 

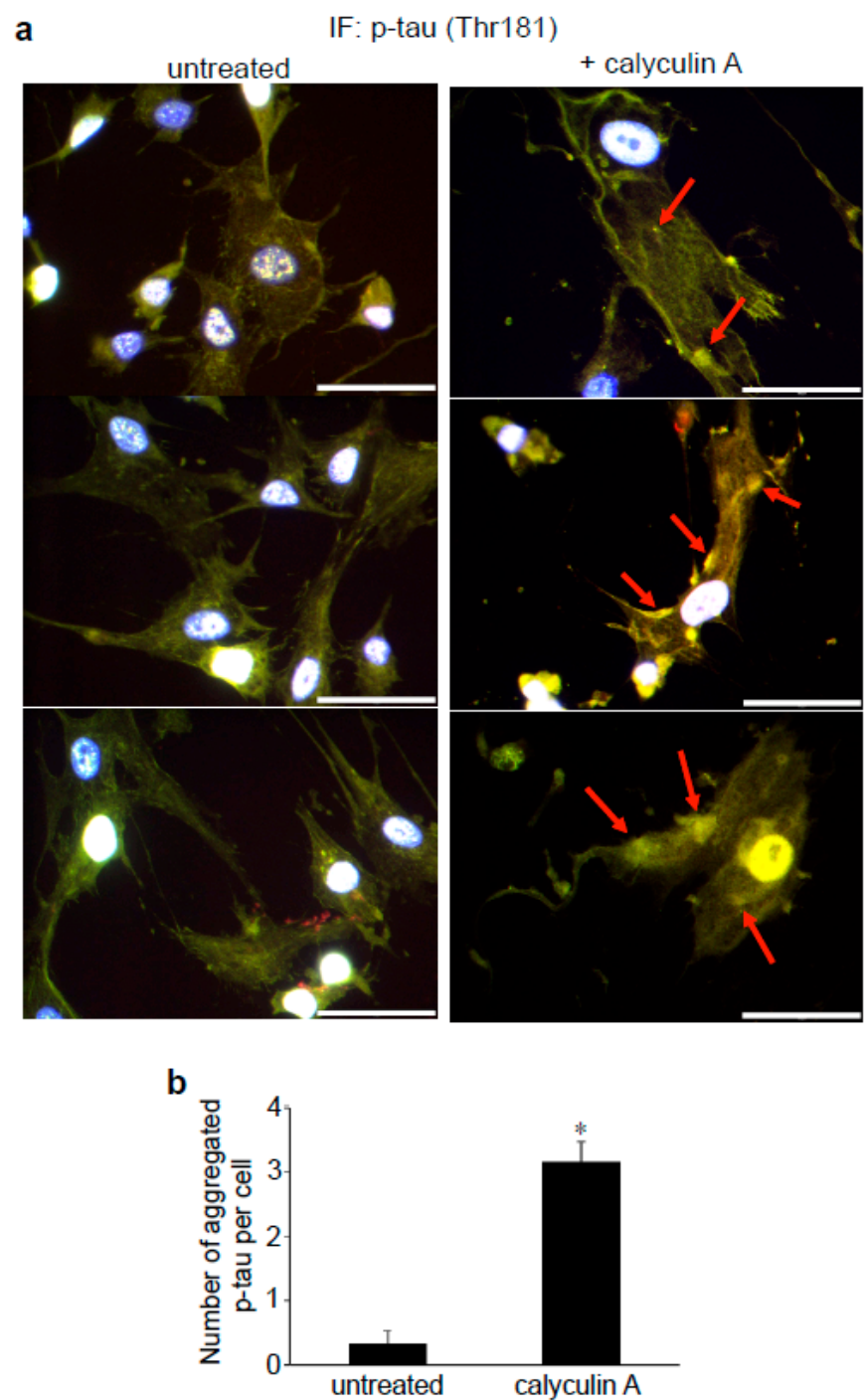

Figure 5. Calyculin A disturbs phosphorylated tau organization. Human pulmonary artery smooth muscle cells were treated with calyculin A $(50 \mathrm{ng} / \mathrm{mL})$ for $30 \mathrm{~min}$ and subjected to immunofluorescence (IF) analysis using the antibody against phosphorylated tau protein at threonine 181, p-tau (Thr181). (a) Three representative images are shown for untreated cells and calyculin A-treated cells. Cells treated with calyculin A show the absence of well-assembled microtubules as well as dispersed phosphorylated tau proteins. The aggregation of phosphorylated tau is also visible, as indicated by the arrows. Scale bars, $50 \mu \mathrm{m}$. (b) Bar graph represents means \pm SEM of aggregated p-tau per cell $(\mathrm{N}=6)$. * Significantly different from untreated at $p<0.05$.

\section{Discussion}

Our findings in the present study showing that tau protein is expressed in various smooth muscle cell types opens up the possibility that this protein may play a pathophysiological role in vascular and airway systems by regulating the various biological mechanisms that it can elicit. As in the nervous system, smooth muscle tau protein can be phosphorylated. This study specifically examined tau phosphorylation at threonine 181 in smooth muscle cells; however, future investigations are warranted to understand the roles of the various phosphorylation sites within the tau protein molecule.

It is noteworthy that phosphorylated tau at threonine 181 specifically assembles in a well-organized fashion in lung smooth muscle cells, while most tau protein molecules seem to be less well organized. These results highlight the potential importance of the threonine 181 phosphorylation of tau in smooth muscle cell biology. Further, as calyculin A-inhibitable protein phosphatase type 1 is known to 
participate in the structure and functioning of smooth muscle myosin light chain phosphatase [39], our findings indicate that tau phosphorylation may be involved in the muscle contraction.

Our finding that calyculin A promotes the aggregation of tau in lung vascular and airway smooth muscle cells is also noteworthy, in that the tau aggregation seen in neurodegenerative diseases could also occur in lung smooth muscle cells. Further, our results consistently showing the formation of higher molecular weight species corresponding to the multimers of tau protein by the calyculin $\mathrm{A}$ treatment of cells suggest the possible use of this protein phosphatase inhibitor for researching tau aggregation in brain cells to combat Alzheimer's disease. Boban et al. [40] reported that okadaic acid, another inhibitor of protein phosphatase types 1 and 2A, promoted the formation of high molecular weight tau species in SH-SY5Y neuroblastoma cells. However, this tau species had a molecular weight of around $100 \mathrm{kDa}$, which is not consistent with the products of tau aggregation.

In summary, the present study showed, for the first time, that smooth muscle cells express tau protein, and that smooth muscle tau is capable of being phosphorylated and aggregated. Future studies to further understand the properties of smooth muscle tau protein should shed light on normal cell biology, as well as on therapeutic strategies to combat a wide variety of diseases that affect smooth muscle cells. The findings of the present study in lung vascular and airway smooth muscle cells also specifically highlight the possible importance of tau in lung pathophysiology.

Author Contributions: Conceptualization, Y.J.S.; methodology, N.V.S., Y.J.S.; validation, Y.J.S.; formal analysis, N.V.S., Y.J.S.; investigation, N.V.S., S.S., N.E.S., V.R., L.M., S.G.G., Y.F.I., Y.J.S.; resources, S.G.G., Y.J.S.; writing_-original draft preparation, N.V.S., Y.J.S.; writing-review and editing, N.V.S., S.S., N.E.S., V.R., L.M., S.G.G., Y.F.I., Y.J.S.; visualization, N.V.S., Y.J.S.; supervision, Y.J.S.; project administration, Y.J.S.; funding acquisition, Y.J.S. All authors have read and agreed to the published version of the manuscript.

Funding: This research was funded by the National Institutes of Health (NIH), grant numbers R01HL072844, R21AI142649, R03AG059554, and R03AA026516 to Y.J.S. The content is solely the responsibility of the authors and does not necessarily represent the official views of the NIH.

Conflicts of Interest: The authors declare no conflict of interest.

\section{References}

1. Grundke-Iqbal, I.; Iqbal, K.; Tung, Y.C.; Quinlan, M.; Wisniewski, H.M.; Binder, L.I. Abnormal phosphorylation of the microtubule-associated protein tau (tau) in Alzheimer cytoskeletal pathology. Proc. Natl. Acad. Sci. USA 1986, 83, 4913-4917. [CrossRef] [PubMed]

2. Binder, L.I.; Frankfurter, A.; Rebhun, L.I. The distribution of tau in the mammalian central nervous system. J. Cell Biol. 1985, 101, 1371-1378. [CrossRef] [PubMed]

3. Qiang, L.; Sun, X.; Austin, T.O.; Muralidharan, H.; Jean, D.C.; Liu, M.; Yu, W.; Baas, P.W. Tau does not stabilize axonal microtubules but rather enables them to have long labile domains. Curr. Biol. 2018, 28, 2181-2189. [CrossRef] [PubMed]

4. Evans, L.D.; Wassmer, T.; Fraser, G.; Smith, J.; Perkinton, M.; Billinton, A.; Livesey, F.J. Extracellular monomeric and aggregated tau efficiently enter human neurons through overlapping but distinct pathways. Cell Rep. 2018, 22, 3612-3624. [CrossRef]

5. Drubin, D.G.; Kirschner, M.W. Tau protein function in living cells. J. Cell Biol. 1986, 103, 2739-2746. [CrossRef]

6. Weingarten, M.D.; Lockwood, A.H.; Hwo, S.Y.; Kirschner, M.W. A protein factor essential for microtubule assembly. Proc. Natl. Acad. Sci. USA 1975, 72, 1858-1862. [CrossRef]

7. Saha, P.; Sen, N. Tauopathy: A common mechanism for neurodegeneration and brain aging. Mech. Ageing Dev. 2019, 178, 72-79. [CrossRef]

8. Mudher, A.; Colin, M.; Dujardin, S.; Medina, M.; Dewachter, I.; Alavi Naini, S.M.; Mandelkow, E.M.; Mandelkow, E.; Buee, L.; Goedert, M.; et al. What is the evidence that tau pathology spreads through prion-like propagation? Acta Neuropathol. Commun. 2017, 5, 99. [CrossRef]

9. Mukrasch, M.D.; von Bergen, M.; Biernat, J.; Fischer, D.; Griesinger, C.; Mandelkow, E.; Zweckstetter, M. The "jaws" of the tau-microtubule interaction. J. Biol. Chem. 2017, 282, 12230-12239. [CrossRef] 
10. Narasimhan, S.; Guo, J.L.; Changolkar, L.; Stieber, A.; McBride, J.D.; Silva, L.V.; He, Z.; Zhang, B.; Gathagan, R.J.; Trojanowski, J.Q.; et al. Pathological tau strains from human brains recapitulate the diversity of Tauopathies in nontransgenic mouse brain. J. Neurosci. 2017, 37, 11406-11423. [CrossRef]

11. Rossi, G.; Dalprà, L.; Crosti, F.; Lissoni, S.; Sciacca, F.L.; Catania, M.; Di Fede, G.; Mangieri, M.; Giaccone, G.; Croci, D.; et al. A new function of microtubule-associated protein tau: Involvement in chromosome stability. Cell Cycle 2008, 7, 1788-1794. [CrossRef] [PubMed]

12. Rossi, G.; Conconi, D.; Panzeri, E.; Redaelli, S.; Piccoli, E.; Paoletta, L.; Dalprà, L.; Tagliavini, F. Mutations in MAPT gene cause chromosome instability and introduce copy number variations widely in the genome. J. Alzheimers Dis. 2013, 33, 969-982. [CrossRef] [PubMed]

13. Ittner, L.M.; Ke, Y.D.; Delerue, F.; Bi, M.; Gladbach, A.; van Eersel, J.; Wölfing, H.; Chieng, B.C.; Christie, M.J.; Napier, I.A.; et al. Dendritic function of tau mediates amyloid-beta toxicity in Alzheimer's disease mouse models. Cell 2010, 142, 387-397. [CrossRef] [PubMed]

14. Johnson, G.V.W.; Hartigan, J.A. Tau protein in normal and Alzheimer's disease brain: An update. J. Alzheimers Dis. 1999, 1, 329-351. [CrossRef] [PubMed]

15. Braak, H.; Braak, E. Neuropathological stageing of Alzheimer-related changes. Acta Neuropathol. 1991, 82, 239-259. [CrossRef]

16. Vuono, R.; Winder-Rhodes, S.; de Silva, R.; Cisbani, G.; Drouin-Ouellet, J. The role of tau in the pathological process and clinical expression of Huntington's disease. Brain 2015, 138, 1907-1918. [CrossRef]

17. Fernández-Nogales, M.; Cabrera, J.R.; Santos-Galindo, M.; Hoozemans, J.J.; Ferrer, I.; Rozemuller, A.J.; Hernández, F.; Avila, J.; Lucas, J.J. Altered levels and isoforms of tau and nuclear membrane invaginations in Huntington's disease. Front. Cell. Neurosci. 2019, 13, 574. [CrossRef]

18. Ballatore, C.; Lee, V.M.; Trojanowski, J.Q. Tau-mediated neurodegeneration in Alzheimer's disease and related disorders. Nat. Rev. Neurosci. 2007, 8, 663-672. [CrossRef]

19. Chin, S.S.; Goldman, J.E. Glial inclusions in CNS degenerative diseases. J. Neuropathol. Exp. Neurol. 1996, 55, 499-508. [CrossRef]

20. Feany, M.B.; Dickson, D.W. Neurodegenerative disorders with extensive tau pathology: A comparative study and review. Ann. Neurol. 1996, 40, 139-148. [CrossRef]

21. Komori, T. Tau-positive glial inclusions in progressive supranuclear palsy, corticobasal degeneration and Pick's disease. Brain Pathol. 1999, 9, 663-679. [CrossRef] [PubMed]

22. Poorkaj, P.; Bird, T.D.; Wijsman, E.; Nemens, E.; Garruto, R.M.; Anderson, L.; Andreadis, A.; Wiederholt, W.C.; Raskind, M.; Schellenberg, G.D. Tau is a candidate gene for chromosome 17 frontotemporal dementia. Ann. Neurol. 1998, 43, 815-825. [CrossRef] [PubMed]

23. Wang, Y.; Mandelkow, E. Tau in physiology and pathology. Nat. Rev. Neurosci. 2016, 17, 5-21. [CrossRef] [PubMed]

24. Šimić, G.; Babić Leko, M.; Wray, S.; Harrington, C.; Delalle, I.; Jovanov-Milošević, N.; Bažadona, D.; de Silva, R.; Di Giovanni, G.; Wischik, C.; et al. Tau protein hyperphosphorylation and aggregation in Alzheimer's disease and other tauopathies, and possible neuroprotective strategies. Biomolecules 2016, 6, 6. [CrossRef] [PubMed]

25. Khurana, V.; Lu, Y.; Steinhilb, M.L.; Oldham, S.; Shulman, J.M.; Feany, M.B. TOR-mediated cell-cycle activation causes neurodegeneration in a Drosophila tauopathy model. Curr. Biol. 2006, 16, 230-241. [CrossRef]

26. Steinhilb, M.L.; Dias-Santagata, D.; Mulkearns, E.E.; Shulman, J.M.; Biernat, J.; Mandelkow, E.M.; Feany, M.B. $\mathrm{S} / \mathrm{P}$ and T/P phosphorylation is critical for tau neurotoxicity in Drosophila. J. Neurosci. Res. 2007, 85, 1271-1278. [CrossRef]

27. Ingelson, M.; Vanmechelen, E.; Lannfelt, L. Microtubule-associated protein tau in human fibroblasts with the Swedish Alzheimer mutation. Neurosci. Lett. 1996, 220, 9-12. [CrossRef]

28. Thurston, V.C.; Zinkowski, R.P.; Binder, L.I. Tau as a nucleolar protein in human nonneural cells in vitro and in vivo. Chromosoma 1996, 105, 20-30. [CrossRef]

29. Sotiropoulos, I.; Galas, M.C.; Silva, J.M.; Skoulakis, E.; Wegmann, S.; Maina, M.B.; Blum, D.; Sayas, C.L.; Mandelkow, E.M.; Mandelkow, E.; et al. Atypical, non-standard functions of the microtubule associated tau protein. Acta Neuropathol. Commun. 2017, 5, 91. [CrossRef]

30. Spillantini, M.G.; Goedert, M. Tau pathology and neurodegeneration. Lancet Neurol. 2013, 12, 609-622. [CrossRef] 
31. Bou Samra, E.; Buhagiar-Labarchede, G.; Machon, C.; Guitton, J.; Onclercq-Delic, R.; Green, M.R.; Alibert, O.; Gazin, C.; Veaute, X.; Amor-Gueret, M. A role for tau protein in maintaining ribosomal DNA stability and cytidine deaminase-deficient cell survival. Nat. Commun. 2017, 8, 693. [CrossRef] [PubMed]

32. Tsartsalis, S.; Xekardaki, A.; Hof, P.R.; Kovari, E.; Bouras, C. Early Alzheimer-type lesions in cognitively normal subjects. Neurobiol. Aging 2018, 62,34-44. [CrossRef] [PubMed]

33. Meier, S.; Bell, M.; Lyons, D.N.; Rodriguez-Rivera, J.; Ingram, A.; Fontaine, S.N.; Mechas, E.; Chen, J.; Wolozin, B.; LeVine, H.; et al. Pathological tau promotes neuronal damage by impairing ribosomal function and decreasing protein synthesis. J. Neurosci. 2016, 36, 1001-1007. [CrossRef] [PubMed]

34. Frost, B.; Hemberg, M.; Lewis, J.; Feany, M.B. Tau promotes neurodegeneration through global chromatin relaxation. Nat. Neurosci. 2014, 7, 357-366. [CrossRef]

35. Hamdane, M.; Bretteville, A.; Sambo, A.V.; Schindowski, K.; Begard, S.; Delacourte, A.; Bertrand, P.; Buee, L. p25/Cdk5-mediated retinoblastoma phosphorylation is an early event in neuronal cell death. J. Cell Sci. 2005, 118, 1291-1298. [CrossRef]

36. Burnouf, S.; Martire, A.; Derisbourg, M.; Laurent, C.; Belarbi, K.; Leboucher, A.; Fernandez-Gomez, F.J.; Troquier, L.; Eddarkaoui, S.; Grosjean, M.E.; et al. NMDA receptor dysfunction contributes to impaired brain-derived neurotrophic factor-induced facilitation of hippocampal synaptic transmission in a tau transgenic model. Aging Cell 2013, 12, 11-23. [CrossRef]

37. Lerea, K.M.; Venjara, A.Y.; Olson, S.C.; Kelly, M.R. Threonine phosphorylation of integrin beta3 in calyculin A-treated platelets is selectively sensitive to 5'-iodotubercidin. Biochim. Biophys. Acta 2007, 1773, 185-191. [CrossRef]

38. Nishikawa, M.; Toyoda, H.; Saito, M.; Morita, K.; Tawara, I.; Deguchi, K.; Kuno, T.; Shima, H.; Nagao, M.; Shirakawa, S. Calyculin A and okadaic acid inhibit human platelet aggregation by blocking protein phosphatases types 1 and 2A. Cell. Signal. 1994, 6, 59-71. [CrossRef]

39. Takai, A.; Eto, M.; Hirano, K.; Takeya, K.; Wakimoto, T.; Watanabe, M. Protein phosphatase 1 and 2A and their naturally occurring inhibitors: Current topics in smooth muscle physiology and chemical biology. J. Physiol. Sci. 2018, 68, 1-17. [CrossRef]

40. Boban, M.; Babić Leko, M.; Miškić, T.; Hof, P.R.; Šimić, G. Human neuroblastoma SH-SY5Y cells treated with okadaic acid express phosphorylated high molecular weight tau-immunoreactive protein species. J. Neurosci. Methods 2019, 319, 60-68. [CrossRef]

Publisher's Note: MDPI stays neutral with regard to jurisdictional claims in published maps and institutional affiliations.

(C) 2020 by the authors. Licensee MDPI, Basel, Switzerland. This article is an open access article distributed under the terms and conditions of the Creative Commons Attribution (CC BY) license (http://creativecommons.org/licenses/by/4.0/). 